\title{
The Consumption of Anesthetic Agents During One-Lung Ventilation and A Cost Analysis: A Comparison of Two Techniques
}

\author{
(1) Fatih Doğu Geyik, ${ }^{1}$ (1) Özlem Sezen, ${ }^{1}$ (을 Banu Çevik, ${ }^{1}$ (1) Recep Demirhan²
}

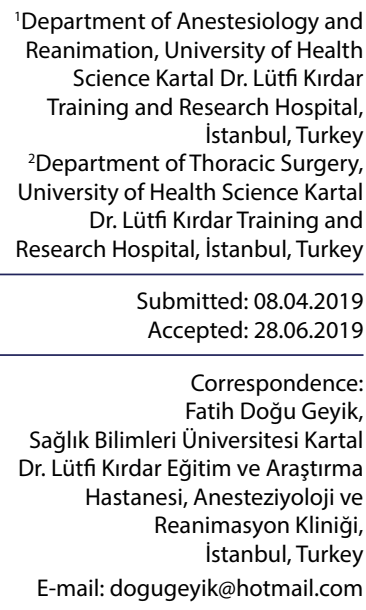

'Department of Anestesiology and Reanimation, University of Health Science Kartal Dr. Lütfi Kırdar Training and Research Hospital, İstanbul, Turkey

${ }^{2}$ Department of Thoracic Surgery, University of Health Science Karta Dr. Lütfi Kırdar Training and Research Hospital, İstanbul, Turkey

Submitted: 08.04.2019 Accepted: 28.06.2019

Correspondence: Fatih Doğu Geyik,

Sağlık Bilimleri Üniversitesi Kartal Dr. Lütfi Kırdar Eğitim ve Araştırma Hastanesi, Anesteziyoloji ve Reanimasyon Kliniği, İstanbul, Turkey

E-mail: dogugeyik@hotmail.com

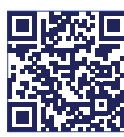

Keywords: Cost analysis; economics; one-lung ventilation; pharmaceutical; thoracic surgery. Attribution-NonCommercial 4.0 International License.

\begin{abstract}
Objective: This prospective, randomized clinical trial aims to compare the direct cost of two anesthetic techniques used in thoracic surgery during one-lung ventilation (OLV).

Methods: In this study, adult patients scheduled for thoracic surgery under general anesthesia were randomized to receive either inhalational (deflurane) or total intravenous anesthesia (propofol), with a continuous infusion of remifentanil in both groups. The depth of anesthesia was maintained at a sustained bispectral index value of $40 \pm 10$. The total quantity of drugs dispensed was estimated, and a cost analysis was performed using hospital pharmacy prices. The patients' demographic information, perioperative characteristics, and recovery time needed to achieve a modified Aldrete score of $\geq 8$ were recorded.
\end{abstract}

Results: In total, 60 patients were enrolled in this study. Patients' demographic details and the duration of anesthesia were comparable between groups. There was no statistically significant difference between the groups with respect to perioperative surgical characteristics. In a $2 \mathrm{~L} /$ minute fresh gas flow, the consumption of desflurane was $120.9 \pm 75.37 \mathrm{~mL}$. The cost of desflurane-balanced anesthesia was significantly greater than that of propofol $(p<0.00 \mathrm{I})$ with comparable clinical characteristics.

Conclusion: Inhalational-based balanced anesthesia is an important point of consideration from a pharmacoeconomical aspect. Low flow anesthesia studies will be important for costsaving in all general anesthesia applications using inhalational anesthetics, including OLV used during thoracic surgery.

\section{INTRODUCTION}

One-lung ventilation (OLV) provides anatomical isolation of the healthy lung from the pathological process of the other to facilitate a clear surgical field for pulmonary and other thoracic surgeries. ${ }^{[1]}$ Anesthesia during OLV is maintained either by delivery of inhalational anesthetics to the ventilated lung or by infusion of intravenous agents. Comparative studies of two techniques have indicated no evidence of the superiority of either technique with respect to patient outcomes. ${ }^{[2]}$ Due to economic constraints, pharmacoeconomical implications and cost-effectiveness have become even more important to healthcare decision-makers worldwide. In addition to financial challenges, metabolic products of inhalation anesthetic drugs are released into a hospital's sewage system and that a large proportion of volatile agents are exhaled and scavenged by anesthesia machines, which creates a severe environmental and atmospheric pollution. ${ }^{[3]}$ Health professionals and the environmental health community have an obligation to inform, advice, and implement changes to address these

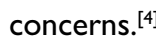

There are many comparisons of total intravenous anesthesia (TIVA) and inhalational agents ${ }^{[5-9]}$, but studies concerning the consumption of anesthetic agents and cost analysis of use in OLV are limited. The present study aims to evaluate the total quantity of intravenous and inhalational anesthetic agents used during OLV and to discuss the aspect of the cost-effectiveness of these two techniques with respect to the current literature. 


\section{MATERIALS AND METHODS}

This prospective, randomized, controlled study was conducted after receiving the approval of the Ethics Committee of Kartal Dr. Lütfi Kırdar Training and Research Hospital (20|8/5|4/I3I/3-|3.06.20I8) and the written informed consent of all of the participants according to the Good Clinical Practice guidelines and the principles of the Declaration of Helsinki.

Patients scheduled for thoracic surgery requiring OLV were included in this study, excluding patients $<18$ years of age, and patients with a body mass index of $>30 \mathrm{~kg}$ $\mathrm{m}^{-2}$, American Society of Anesthesiologist (ASA) class VI, symptomatic renal or liver failure, preoperative intubated status or critical care patients under mechanical ventilation or continuous infusion of inotropes or vasopressors, pregnancy, emergency cases and a previous history of thoracic surgery.

According to institution protocol, preoperative evaluation included assessment of total blood count, coagulation parameters, renal and hepatic function tests, chest $X$-ray and an electrocardiogram performed by an anesthesiologist for ASA risk classification

The patients were randomly allocated to two groups to receive either inhalational anesthesia with desflurane (Suprane, Baxter International Inc., Deerfield, IL,USA) or continuous intravenous (IV) infusion of propofol (propofol 2\%; Fresenius Kabi AG, Bad Homburg vor der Höhe, Germany) for the maintenance of anesthesia using a computer-generated randomization program operated by another clinician blinded to this study.

In the preoperative care unit, intravenous (IV) access was established with an I8-G IV cannula, and all of the patients were premedicated with 0.02 to $0.03 \mathrm{mg} \mathrm{kg}^{-1} \mathrm{IV}$ midazolam 30 minutes prior to surgery. As a standard pre-surgical procedure, 3-lead electrocardiography, pulse oximetry and non-invasive blood pressure monitoring (Infinity Delta XL, Drager, Germany) were performed after transport to the operating theatre. Before induction of anesthesia, a bispectral index sensor (BIS QUATRO; Medtronic plc, Dublin, Ireland) was placed on the patient's forehead and connected to a BIS Vista monitor (Medtronic plc, Dublin, Republic of Ireland). Initial values were recorded as baseline parameters.

In each group, general anesthesia was induced with I to 2 $\mu \mathrm{g} \mathrm{kg}^{-1}$ fentanyl (VEM İlaç AŞ, Tekirdağ, Turkey) followed by propofol administration at 2 to $3 \mathrm{mg} \mathrm{kg}^{-1}$ until achieving the loss of verbal response and eyelash reflex. The clinical endpoint was sustained a BIS value of $40 \pm 10$. After appropriate mask ventilation was ensured, neuromuscular blocking was established with IV $0.5 \mathrm{mg} / \mathrm{kg}$ rocuronium (Muscuron, Koçak Farma İlaç ve Kimya Sanayi A.Ş., Istanbul, Turkey) and tracheal intubation was completed with an appropriate sized, left or right double-lumen tube (DLT) (Shiley; Medtronic plc, Dublin, Republic of Ireland). The correct position of the tube was confirmed with a flexible fiberoptic bronchoscope (EB-530-P; Fujifilm Corp.,
Tokyo, Japan). Initial mechanical ventilation was initiated with a tidal volume of 6 to $8 \mathrm{~mL} \mathrm{~kg}^{-1}$ and a respiratory rate of 12 breaths minute ${ }^{-1}$ during 2 -lung ventilation to adjust to an end-tidal carbon dioxide tension of 30 to $40 \mathrm{mmHg}$. A Drager Perseus A 500 anesthesia machine (Drägerwerk AG, Lübeck, Germany) was used during all of the study procedures using the setting of each patient's age, gender, height, and weight to calculate desflurane delivery.

In Group D, maintenance of anesthesia was provided using desflurane 5.0 to $7.0 \mathrm{vol} \%$ with a mixture of air and oxygen ( $\mathrm{FiO}_{2}: 0.5$ in 2-lung ventilation) in a fresh gas flow of $2 \mathrm{~L} /$ minute. Group $P$ received a propofol infusion initiated at a rate of 2 to $4 \mathrm{mg} \mathrm{kg}^{-1}$ hour-1 via a syringe pump (Aitecs 2016; Viltechmeda UAB, Vilnius, Lithuania). In each group, the targeted endpoint was to achieve a BIS value of $40 \pm 10$. A continuous remifentanil (Rentanil; Vem Ilaç San.Tic. A.Ş., Tekirdağ, Turkey) infusion was also administered in both groups of patients with an initial dose of I to $2 \mu \mathrm{g} \mathrm{kg-1}$ hour $^{-1}$ and adjusted to maintain blood pressure and heart rate within $\pm 20 \%$ of the baseline value. Neuromuscular monitoring was not used. Intermittent boluses of rocuronium were administered.

After the patients were placed in the right or left lateral decubitus position, the location of the DLT was verified once more with a fiberoptic bronchoscope before clamping the tracheal lumen. Tidal volume was set at 4 to 6 $\mathrm{mL} / \mathrm{kg}$ and the respiratory rate was adjusted to maintain normocapnia. The patients were ventilated under $60 \%$ to $80 \%$ oxygen during OLV. If the arterial oxygen saturation dropped below $90 \%$, the tube position, aspiration of the bronchial lumen, the increment of the $\mathrm{FiO}_{2}$, respiratory rate, and/or tidal volume were assessed. During OLV, 3 to $5 \mathrm{~cm} \mathrm{H}_{2} \mathrm{O}$ positive end-expiratory pressure was sequentially applied to the ventilated lung. The length of time until ventilation of both lungs at the completion of the thoracic procedure was considered the duration of OLV.

At the conclusion of the surgery, the cumulative neuromuscular blockade was assessed using the acceleromyograhic technique with a neuromuscular monitor (TOFWatch; Organon Ltd., Swords, Ireland) and a train-of-four of $\geq 80$ was used to indicate recovery. Sugammadex (Bridion; Merck\& Co., Inc., Kenilworth, NJ, USA) was used as a reversal agent in an IV dose of $2 \mathrm{mg} \mathrm{kg}^{-1}$. Postoperative analgesia was provided using IV tramadol I mg/ kg (Tradolex; Mefar İlaç Sanayi A.Ş., İstanbul, Turkey) in a combination of IV paracetamol 8 to $10 \mathrm{mg} \mathrm{kg}^{-1}$ (Perfalgan; Bristol-Myers Squibb, NY, NY, USA).

Following extubation, the patients were transferred to the post-anesthesia care unit. When patients attained a modified Aldrete score of $\geq 8$, they were discharged to the thoracic surgery clinic.

\section{Data collection}

Patient characteristics of age, gender, height, weight, ASA physical status, and comorbidities were recorded on prepared forms. Hemodynamic parameters, BIS values, 
Table I. The hospital inpatient pharmacy prices of the study drugs*

\begin{tabular}{lc}
\hline Drug & Price \\
\hline Desflurane & $\$ 38.4 / 240 \mathrm{~mL}$ \\
& $(\$ 0.16 / \mathrm{mL})$ \\
Propofol 2\% & $\$ 2.7 / 50 \mathrm{~mL}$ \\
Remifentanil & $\$ 2.3 / 2 \mathrm{mg}$ \\
Rocuronium & $\$ 0.61 / 50 \mathrm{mg}$ \\
\hline *Currency conversion rate was I $\$=6$ TRY (September 28,2018$).$
\end{tabular}

$\mathrm{SpO}_{2}, \mathrm{EtCO}_{2}$, and ventilator settings were recorded at 15-minute intervals throughout the surgery. The type of surgical procedure and the duration of anesthesia, OLV, and the operation were also documented.

Total pharmacy cost per patient was estimated by the total amount of drugs dispensed multiplied by the hospital inpatient pharmacy prices (Table I). In Group D, the desflurane consumption was recorded from the anesthesia machine monitor in milliliters calculated through the gas usage during the surgical procedure. In this group, the amount of opened remifentanil and rocuronium vial during the entire duration of anesthesia was also included in the total cost.

In Group P, the total volume of propofol and remifentanil was estimated based on the infused drug from the syringe pump. The total quantity of drugs used and wasted during anesthesia was included in the cost analysis. The price of the extension line and syringe used in the infusion pump were also added to the total cost analysis of Group $P$ (\$2.30 each). The time to achieve a modified Aldrete score of $\geq 8$ was accepted as the recovery time in both groups of patients.

\section{Statistical analysis}

Data were expressed as mean \pm SD or number (\%). Comparisons were conducted using the t-test for continuous variables, and Pearson's chi-square test or Fisher's exact test for non-continuous variables. The analysis was performed using PASW Statistics for Windows, Version 18.0 (SPSS Inc., Chicago, IL, USA). The level of significance was accepted as $p<0.05$ in all analyses.

\section{RESULTS}

A total of 60 patients were included in this study. The demographic data were comparable between the two groups $(p>0.05)$ (Table 2). There was no statistically significant difference with respect to the type of surgery or the duration of anesthesia or surgery $(p>0.05)$ (Table 3$)$. Intraoperative characteristics of the patients were comparable between study groups. Systolic blood pressure showed a statistical significance, but this difference was clinically negligible (Table 4). The cost/patient was $\$ 23.78 \pm$ I I.99 in Group D and \$1 I.56 \pm 2.57 in Group P, which revealed a great significance $(p<0.00 \mathrm{I})$ (Table 5$)$. Bispectral index changes are shown in the graphic (Fig. I).

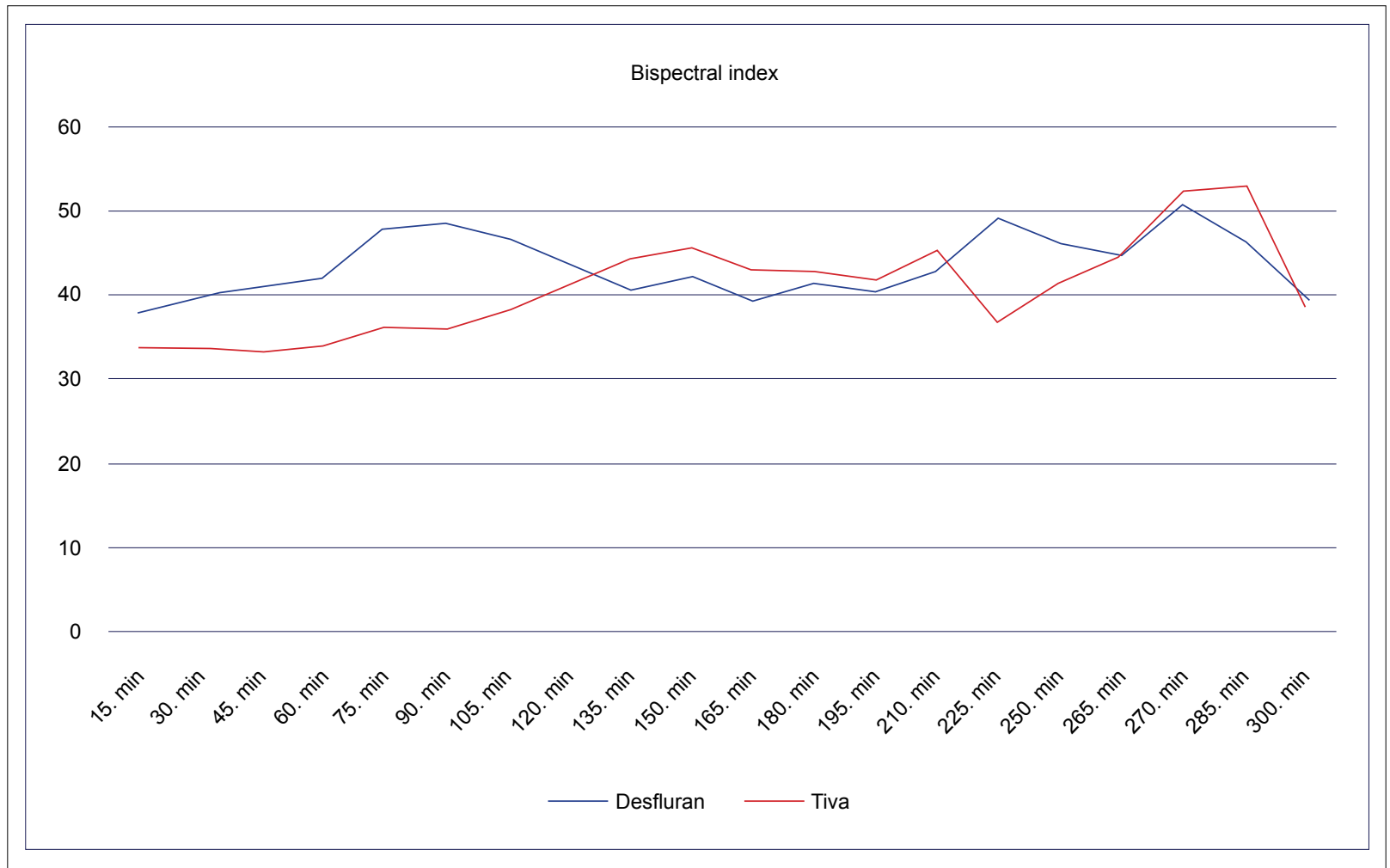

Figure 1. BIS changes during surgery. 
Table 2. The patients' characteristics

\begin{tabular}{lccc}
\hline Variables & $\begin{array}{c}\text { Group D } \\
(\mathbf{n = 3 0})\end{array}$ & $\begin{array}{c}\text { Group P } \\
(\mathbf{n = 3 0 )}\end{array}$ & $\mathbf{p}$ \\
\hline $\begin{array}{l}\text { Age (years) } \\
\text { Gender* }\end{array}$ & $55.9 \pm 17.0$ & $54.8 \pm 19.8$ & 0.819 \\
$\quad$ Male & $21(70.0)$ & $20(67.0)$ & 0.781 \\
$\quad$ Female & $9(30.0)$ & $9(33.0)$ & \\
Height (cm) & $168.8 \pm 8.6$ & $168.5 \pm 9.3$ & 0.897 \\
Weight (kg) & $72.0 \pm 14.4$ & $76.0 \pm 16.3$ & 0.319 \\
ASA status & & & \\
$\quad$ I & $2(6.6)$ & $5(16.7)$ & \\
$\quad$ II & $14(46.7)$ & $14(46.7)$ & 0.143 \\
$\quad$ III & $14(46.7)$ & $11(36.7)$ & \\
Comorbidity $^{* *}$ & $12(40.0)$ & $13(43.3)$ & 0.793 \\
\hline
\end{tabular}

"Data expressed as mean $\pm S D$ or "the number of patients $(n)$ and the percentage (\%); ASA: American Society of Anesthesiologists.

\section{DISCUSSION}

In this study, the cost of desflurane-balanced anesthesia in a $2 \mathrm{~L}$ minute ${ }^{-1}$ fresh gas flow during OLV was significantly greater than that of TIVA. This outcome led to a reconsideration of the importance of gas flow during general anesthesia and led to new clinical research concerning low-flow anesthesia during thoracic surgery.

A literature review revealed many cost-analysis studies of various anesthetic drugs and techniques, but studies focused on OLV were limited. ${ }^{[6,7,10-15]}$ Although the expense of anesthesia accounts for a small part of a single surgical procedure, the total expense constitutes a big budget when the large number of surgeries performed each day is considered. ${ }^{[16]}$ Direct costs related to drugs, medical devices, recovery time, side effects, additional drug administrations,; indirect costs, such as rent, salaries, building equipment costs (fixed costs), and variable costs according to the quantity and quality of the surgical procedures are the main components of total cost analyses. ${ }^{[17]}$

In parallel with surgical developments, OLV is now being used more frequently in many surgical procedures other than thoracic interventions, such as esophagus, aorta, or thoracic spine surgeries. ${ }^{[18]}$ The means of providing general anesthesia is an important decision in these procedures, and DLTs are the most commonly used devices. Anesthetic management is complex, extending from the insertion of the DLT to the postoperative recovery of the patient. Desflurane and propofol are the anesthetic agents most preferred due to their short-acting properties with a low blood-gas partition coefficient and low context-sensitive halftime, respectively. ${ }^{[19]}$

An animal study revealed that desflurane depressed hypoxic pulmonary vasoconstriction in a dose-dependent manner and impaired oxygenation during OLV. ${ }^{[20]}$ Chao et al. ${ }^{[19]}$ also indicated that the administration of propofolremifentanil TIVA might be a better choice in preventing hypoxemia during OLV compared with desflurane-remifentanil balanced anesthesia. Cardiac output, the arterial partial pressure of oxygen $\left(\mathrm{PaO}_{2}\right)$ and mixed venous $\mathrm{PO}_{2}$ also decreased with desflurane inhalation, whereas perfusion of the non-ventilated lung and shunt fraction remained comparable with the propofol infusion in an animal model. [21] An investigation with gas chromatography indicated that both arterial and venous blood concentration of desflurane diminished up to $29 \%$ during OLV due to ventilation-perfusion mismatch. ${ }^{[22]}$

In our study, no difference was observed in oxygenation between desflurane and propofol anesthesia during OLV. This was not the main objective of the study, so this result should be interpreted with some limitations. We did not measure the pulmonary shunt fraction or pulmonary perfusion, which could affect the arteriovenous shunt fraction or the ventilation-perfusion mismatch. The amount of desflurane or propofol administration was titrated according to BIS monitoring and hemodynamic variability, so the results reflected no specific anesthetic dose. Our focus in this study was the economic perspective related to these two anesthesia techniques that are the standard clinical practice in thoracic surgery in our hospital.

Gulbayrak et al. ${ }^{[23]}$ demonstrated that BIS values did not correlate with the hemodynamic response but were consistent with endocrine responses. In our study, we achieved

Table 3. Data related to the surgical procedures

\begin{tabular}{|c|c|c|c|}
\hline Variables & Group D $(n=30)$ & Group P $(n=30)$ & $\mathbf{p}$ \\
\hline \multicolumn{4}{|l|}{ Types of surgery* } \\
\hline Anatomical resection & $12(40.0)$ & II(36.7) & \\
\hline Wedge resection & $6(20.0)$ & $6(20.0)$ & 0.787 \\
\hline Bullectomy & $3(10.0)$ & $3(10.0)$ & \\
\hline Others & $9(30.0)$ & $10(33.3)$ & \\
\hline Duration of anesthesia $(\min )^{* *}$ & $189.6 \pm 96.7$ & $201.0 \pm 87.6$ & 0.636 \\
\hline Duration of OLV $(\mathrm{min})^{* *}$ & $|28.5 \pm 7| .5$ & $136.0 \pm 70.7$ & 0.685 \\
\hline Length of operation $(\mathrm{min})^{* *}$ & $153.3 \pm 90.9$ & $162.5 \pm 78.4$ & 0.678 \\
\hline Time to achieve Aldrete $\geq 8(\mathrm{~min})^{* *}$ & $|9.33 \pm 4.4|$ & $23.30 \pm 4.43$ & 0.881 \\
\hline
\end{tabular}

"Data expressed as the number of the patient $(n)$, and the percentage $(\%)$ or ${ }^{* *}$ mean $\pm S D$; OLV: One-lung ventilation. 
Table 4. Intraoperative characteristics (mean \pm SD)

\begin{tabular}{|c|c|c|c|}
\hline Variables & $\begin{array}{c}\text { Group D } \\
(n=30)\end{array}$ & $\begin{array}{c}\text { Group P } \\
(n=30)\end{array}$ & p \\
\hline $\mathrm{SpO}_{2}(\%)$ & $97.6 \pm 1.7$ & $97.7 \pm 2.0$ & 0.800 \\
\hline HR (beats/min) & $78.2 \pm 12.2$ & $75.8 \pm 13.6$ & 0.479 \\
\hline $\mathrm{ETCO}_{2}$ & $34.5 \pm 3.8$ & $33.0 \pm 4.1$ & 0.166 \\
\hline $\mathrm{SBP}(\mathrm{mmHg})$ & $113.7 \pm 12.1$ & $122.3 \pm 15.8$ & $0.02 *$ \\
\hline $\mathrm{DBP}(\mathrm{mmHg})$ & $65.6 \pm 9.6$ & $69.0 \pm 11.2$ & 0.212 \\
\hline MAP $(\mathrm{mmHg})$ & $84.6 \pm 9.5$ & $89.2 \pm 11.4$ & 0.090 \\
\hline $\mathrm{FiO}_{2}(\%)$ & $65.2 \pm 7.0$ & $68.2 \pm 9.2$ & 0.157 \\
\hline $\mathrm{TV}(\mathrm{mL})$ & $444.1 \pm 31.2$ & $433.9 \pm 41.2$ & 0.285 \\
\hline $\mathrm{RR}(/ \mathrm{min})$ & $15.1 \pm 1.5$ & $15.3 \pm 1.5$ & 0.674 \\
\hline PEEP $\left(\mathrm{cm} \mathrm{H}_{2} \mathrm{O}\right)$ & $3.6 \pm 0.5$ & $3.5 \pm 0.6$ & 0.705 \\
\hline \multicolumn{4}{|l|}{ BIS } \\
\hline Basal & $95.3 \pm 3.8$ & $96.6 \pm 1.4$ & 0.070 \\
\hline Pre-extubation & $66.9 \pm 21.5$ & $73.5 \pm 13.5$ & 0.160 \\
\hline \multicolumn{4}{|c|}{$\begin{array}{l}\text { *p<0.05. BIS: Bispectral index; DBP: diastolic blood pressure; } \mathrm{ETCO}_{2} \text { : End- } \\
\text { tidal carbon dioxide; FiO } \mathrm{F}_{2} \text { : Fraction of inspired oxygen; HR: Heart rate; } \\
\text { PEEP: Peak end-expiratory pressure; RR: Respiratory rate; SBP: Systolic blo- } \\
\text { od pressure; } \mathrm{SpO}_{2} \text { : Peripheral oxygen saturation; TV: Tidal volume, MAP: } \\
\text { Mean arterial pressure. }\end{array}$} \\
\hline
\end{tabular}

Table 5. Consumption of the anesthesia drugs and the cost in each study groups (mean $\pm S D$ )

\begin{tabular}{lccc}
\hline Variables & $\begin{array}{c}\text { Group D } \\
(\mathbf{n = 3 0})\end{array}$ & $\begin{array}{c}\text { Group P } \\
(\mathbf{n = 3 0 )}\end{array}$ & P \\
\hline Desflurane $(\mathrm{mL})$ & $120.9 \pm 75.37$ & - & - \\
Propofol 2\% $(\mathrm{mg})$ & - & $1581.3 \pm 777.1$ & - \\
Remifentanil $(\mu \mathrm{g})$ & $538.2 \pm 618.9$ & $797.3 \pm 653.3$ & 0.120 \\
Rocuronium $(\mathrm{mg})$ & $77.3 \pm 27.1$ & $86.8 \pm 25.1$ & 0.165 \\
Cost (US\$)/patient & $23.78 \pm 11.99$ & $11.56 \pm 2.57^{*}$ & $0.000^{* *}$ \\
\hline
\end{tabular}

"The extension line +syringe cost was included; " $\mathrm{p}<0.001$ statistically highly significant.

similar results. Tiva and desflurane anesthesia have similar hemodynamic effects in patients undergoing coronary artery bypass grafting. ${ }^{[24]}$ In another clinical study, the similar clinical effects of sevoflurane and desflurane have been demonstrated. ${ }^{[25]}$

Anesthesiologists usually choose anesthesia techniques, drugs, and devices during daily practice according to their skills rather than cost-effectiveness. The cost of these agents varies between institutions according to the production and the delivery of the product. Fresh gas flow has a linear correlation with the consumption of inhalational agents. ${ }^{[10,16,26,27,28]}$ The use of a high flow provides greater control of the level of anesthesia but increases the cost. Anesthesia providers usually avoid choosing a low fresh gas flow due to a fear of an uncontrolled depth of anesthesia, hypoxic events, hypercapnia, or potential gas toxicity. ${ }^{[28]}$ With the advent of the modern anesthesia machine, the risks of low-flow anesthesia diminished, but more attention and caution on the part of the anesthesiologist became compulsory. In addition to the considerations regarding economic savings, environmental pollution is another challenging issue. Clinicians and other members of the health community are obliged to become advocates for the prevention of unnecessary waste production with regard to reducing global climate and environmental changes. ${ }^{[3,4,29]}$

In our study, the mean desflurane consumption for each patient was $120.9 \pm 75.37 \mathrm{ml}$ in a $2 \mathrm{~L}$ minute ${ }^{-1}$ fresh gas flow. The price of $1 \mathrm{~mL}$ desflurane is $\$ 0.16$ in our country, so it constitutes a big share of the total anesthesia cost. Different results have been reported with respect to TIVA due to the price diversity between countries. ${ }^{[16,26]}$ The necessity for additional equipment, such as specific pumps, extension lines, and BIS monitoring for the depth of anesthesia result in greater costs associated with this anesthesia technique. A recent study indicated that the use of BIS decreased the consumption of anesthetic drugs but increased the disposable expenses in anesthesia. The authors noted the necessity of additional monitoring during daily practice. ${ }^{[30]}$

We included the price of an infusion syringe and extension line in the cost analysis of the patients in Group P. A BIS electrode was used in all cases, so this expense was excluded from the cost investigation. In our hospital, it is difficult to estimate the indirect, fixed, and variable costs. Therefore, we focused only on the direct costs and did not consider other parameters in this research. Our results revealed a total cost of $\$ 23.78 \pm 11.99$ and $\$ 11.56 \pm 2.57$ in Group D and Group P, respectively, which represented a highly significant difference $(p<0.001)$.

\section{CONCLUSION}

In conclusion, both desflurane-balanced anesthesia and TIVA with propofol provided safe anesthetic management of OLV with comparable clinical characteristics. Our results confirmed the potential significance of low-flow anesthesia as a means of decreasing the consumption of volatile agents. We believe that the decrease in consumption resulted in cost savings as well as less environmental damage. Further clinical studies are required concerning the safety of low-flow anesthesia in OLV to encourage anesthesia experts to consider adapting to the use of lowflow anesthesia in their thoracic anesthesia practice.

\section{Ethics Committee Approval}

This prospective, randomized, controlled study was conducted after receiving the approval of the Ethics Committee of Kartal Dr. Lütfi Kırdar Training and Research Hospital (2018/5I4/I3I/3-13.06.2018).

\section{Informed Consent}

Prospective study.

Peer-review

Internally peer-reviewed.

Authorship Contributions 
Concept: F.D.G., B.Ç.; Design: F.D.G., B.Ç.; Supervision: F.D.G., B.Ç., R.D.; Fundings: F.D.G., Ö.S.; Materials: F.D.G., Ö.S., R.D.; Data: F.D.G, B.Ç.; Analysis: F.D.G., B.Ç., Ö.S.; Literature search: F.D.G., B.Ç.; Writing: F.D.G., B.Ç.; Critical revision: B.Ç., R.D.

\section{Conflict of Interest}

None declared.

\section{REFERENCES}

1. https://www.uptodate.com/contents/lung-isolation-techniques? search $=$ one $\% 20$ lung\%20ventilation $\&$ source $=$ search_re sult\&selectedTitle $=2 \sim 51 \&$ usage_type $=$ default $\&$ display_rank $=2$. Accessed Sep 25, 2019.

2. Módolo NS, Módolo MP, Marton MA, Volpato E, Monteiro Arantes $\mathrm{V}$, do Nascimento Junior P, et al. Intravenous versus inhalation anaesthesia for one-lung ventilation. Cochrane Database Syst Rev 2013;CD006313. [CrossRef]

3. Yasny JS, White J. Environmental implications of anesthetic gases. Anesth Prog 2012;59:154-8. [CrossRef]

4. Schwartz BS, Parker C, Glass TA, Hu H. Global environmental change: what can health care providers and the environmental health community do about it now? Environ Health Perspect 2006;114:1807-12. [CrossRef]

5. Kumar G, Stendall C, Mistry R, Gurusamy K, Walker D. A comparison of total intravenous anaesthesia using propofol with sevoflurane or desflurane in ambulatory surgery: systematic review and metaanalysis. Anaesthesia 2014;69:1138-50. [CrossRef]

6. Okur O, Tekgül ZT, Yeniay O, Külünk Direnç E. Düşük akım anestezi eğitiminin kısa dönemde anestezik gaz tüketimi üzerine etkisi. Tepecik Eğit ve Araşt Hast Dergisi 2016;26:146-150.

7. Erbay RH, Tomatır E, Hancı V, Serin S, Atalay H. Desfluran-N2O, Sevofluran-N2O Minimal Akım ve Propofol-Remifentanil Anestezilerinde Maliyetlerin Karşılaştırılması. Türkiye Klinikleri J Anest Reanim 2009;7:11-8.

8. Chang YT, Wu CC, Tang TY, Lu CT, Lai CS, Shen CH. Differences between Total Intravenous Anesthesia and Inhalation Anesthesia in Free Flap Surgery of Head and Neck Cancer. PLoS One 2016;11:e0147713. [CrossRef]

9. Cattano D, Gomez-Rivera F, Seitan C, Altamirano A, Patel C, Luong A, et al. Post-Operative Effects: Comparison of Total Intravenous and Inhalational Anesthesia. J Anesthe Clinic Res 4:287.

10. Martelli A. Costs optimization in anaesthesia. Acta Biomed 2015;86:38-44.

11. Tyagi A, Venkateswaran V, Jain AK, Verma UC. Cost analysis of three techniques of administering sevoflurane. Anesthesiol Res Pract 2014;2014:459432. [CrossRef]

12. Biro P. Calculation of volatile anaesthetics consumption from agent concentration and fresh gas flow. Acta Anaesthesiol Scand 2014;58:968-72. [CrossRef]

13. $\mathrm{Hu}$ J, He Z. Cost of general anesthesia during radical gastrectomy using different specifications of propofol: cost-minimization analyses. Int J Clin Exp Med 2015;8:21266-78.

14. Hogan PF, Seifert RF, Moore CS, Simonson BE. Cost effectiveness analysis of anesthesia providers. Nurs Econ 2010;28:159-69.

15. De Rojas JO, Syre P, Welch WC. Regional anesthesia versus general anesthesia for surgery on the lumbar spine: a review of the modern literature. Clin Neurol Neurosurg 2014;119:39-43. [CrossRef]

16. Rinehardt EK, Sivarajan M. Costs and wastes in anesthesia care. Curr Opin Anaesthesiol 2012;25:221-5. [CrossRef]

17. Watcha MF, White PF. Economics of anesthetic practice. Anesthesiology 1997;86:1170-96. [CrossRef]

18. Ashok V, Francis J. A practical approach to adult one-lung ventilation. BJA 2018;18:69-74. [CrossRef]

19. Cho YJ, Kim TK, Hong DM, Seo JH, Bahk JH, Jeon Y. Effect of desflurane-remifentanil vs. Propofol-remifentanil anesthesia on arterial oxygenation during one-lung ventilation for thoracoscopic surgery: a prospective randomized trial. BMC Anesthesiol 2017;17:9. [CrossRef]

20. Loer SA, Scheeren TW, Tarnow J. Desflurane inhibits hypoxic pulmonary vasoconstriction in isolated rabbit lungs. Anesthesiology 1995;83:552-6. [CrossRef]

21. Schwarzkopf K, Schreiber T, Preussler NP, Gaser E, Hüter L, Bauer $\mathrm{R}$, et al. Lung perfusion, shunt fraction, and oxygenation during one-lung ventilation in pigs: the effects of desflurane, isoflurane, and propofol. J Cardiothorac Vasc Anesth 2003;17:73-5. [CrossRef]

22. Biricik E, Karacaer F, Güneş Y, Dağlıŏlu N, Efeoğlu P, Ilgınel M, et al. Effect of One-Lung Ventilation on Blood Sevoflurane and Desflurane Concentrations. J Cardiothorac Vasc Anesth 2019;33:442-449.

23. Gülbayrak H, Erhan Ö, Önal SA, Yaşar MA, Gülbayrak K. İnhalasyon ve Propofol Anestezilerinin Nöromüsküler Blok ve Anestezi Derinlik Monitörizasyonlari ile Hemodinamik ve Nöroendokrin Yanitlarinin Karşilaştirilmasi. F.Ü. Sağlık Bil. Dergisi 2004;18:131-137.

24. Özbey T, Başağan Moğol E, Kaya FN, Türker G, Biçer M, Saba D, et al. Çalıssan Kalpte Koroner Arter Baypas Cerrahisinde Desfluran ve Total İntravenöz Anestezi (TIVA)'nin Hemodinami Üzerine Etkilerinin Karşılaştırılması. Turkiye Klinikleri J Anest Reanim 2013;11:128-365.

25. Temizel F, Doğu D, Yildirim G, Arslan G, Çelik G, Arıkan Z. Geriatrik hastalarda desfluran ve Sevofluranın Hemodinami Derlenme ve Kognitif Fonksiyonlara Etkilerinin Karşılaştırılması. Kartal Eğitim ve Araştırma Hastanesi Tip Dergisi 2004;15:33-36.

26. Ozkose Z, Ercan B, Unal Y, Yardim S, Kaymaz M, Dogulu F, et al. Inhalation versus total intravenous anesthesia for lumbar disc herniation: comparison of hemodynamic effects, recovery characteristics, and cost. J Neurosurg Anesthesiol 2001;13:296-302. [CrossRef]

27. Ryksen E, Diedericks BJS. Southern African Journal of Anaesthesia and Analgesia - Calculation of comparative utilisation and cost : a South African perspective on intravenous vs. inhalational anaesthesia for procedures of differing duration : original research. South Afr J Anaesth Analg 2012;18:310-7. [CrossRef]

28. Suttner S, Boldt J. Low-flow anaesthesia. Does it have potential pharmacoeconomic consequences? Pharmacoeconomics 2000;17:585-90.

29. Brattwall M, Warrén-Stomberg M, Hesselvik F, Jakobsson J. Brief review: theory and practice of minimal fresh gas flow anesthesia. Can J Anaesth 2012;59:785-97. [CrossRef]

30. Bocskai T, Loibl C, Vamos Z, Woth G, Molnar T, Bogar L, et al. Cost-effectiveness of anesthesia maintained with sevoflurane or propofol with and without additional monitoring: a prospective, randomized controlled trial. BMC Anesthesiol 2018;18:100. [CrossRef] 
Tek Akciğer Ventilasyonunda İki Farklı Tekniğin Karşılaştırılması ve Maliyet Analizi

Amaç: Bu ileriye yönelik, randomize klinik çalışmanın amacı, tek akciğer ventilasyonu sırasında torasik cerrahide kullanılan iki farklı anestezik tekniğin maliyetini karşılaştırmaktır (TAV).

Gereç ve Yöntem: Genel anestezi altında torasik cerrahi planlanan yetişkin hastalar, her iki grupta da sürekli remifentanil infüzyonu ile inhalasyonal (defluran) veya total intravenöz anestezi (propofol) almak üzere randomize edildi. Anestezi derinliği, $40 \pm 10$ sürekli bispektral indeks değerinde tutuldu. Dağıtılan toplam ilaç miktarı tahmin edildi ve hastane eczane fiyatları kullanılarak bir maliyet analizi yapıldı. Hastaların demografik bilgileri, perioperatif özellikleri ve modifiye Aldrete skorunun $\geq 8$ olması için gereken iyileşme süresi kaydedildi.

Bulgular: Toplamda 60 hasta çalışmaya dahil edildi. Hastaların demografik bilgileri ve anestezi süresi gruplar arasında karşılaştırıldı. Perioperatif cerrahi özellikler açısından gruplar arasında istatistiksel olarak anlamlı fark yoktu. 2 L/dakikalık bir taze gaz akışında, desfluran tüketimi I 20.9 $\pm 75.37 \mathrm{~mL}$ idi. Desfluran dengeli anestezinin maliyeti, karşılaştırılabilir klinik özelliklere sahip olan propofolünkinden $(p<0.00 \mathrm{I})$ anlamlı olarak daha yüksekti.

Sonuç: İnhalasyonel bazlı dengeli anestezi, farmakoekonomik açıdan önemli bir husustur. Düşük akımlı anestezi çalışmaları, torasik cerrahi sırasında kullanılan OLV de dahil olmak üzere inhalasyonel anestezi kullanan tüm genel anestezi uygulamalarında maliyet tasarrufu için önemli olacaktır.

Anahtar Sözcükler: Ekonomik; farmasötik; göğüs cerrahisi; maliyet analizi; tek akciğer ventilasyonu. 